REFLECTIVE PRACTICE

\title{
Inclusion in Times of Covid-19: The Case of International Students in South Africa
}

\author{
Samia Chasi ${ }^{i} \&$ Orla Quinlan ${ }^{\text {ii }}$
}

\section{Abstract}

The Covid-19 pandemic has caused major disruptions to the teaching, learning and research functions of universities around the globe. It has also impacted their internationalisation efforts in significant ways.

From the perspective of South Africa's public higher education sector, this article reflects on how international students at the country's universities have been affected by national and institutional responses to Covid-19. It highlights the specific challenges and constraints international students faced in light of Covid-19 related restrictions such as travel bans, university closures and the national lockdown. In doing so, several aspects of the international student experience are explored, specifically regarding travelling home, communication, accommodation and immigration. The article also addresses the issue of remote learning and academic continuity, arguing that international students, especially those who were outside the borders of South Africa, are at risk of being left behind. It advocates for the inclusion of international students in national and institutional considerations and plans for the successful completion of the 2020 academic year.

The article recognises that, in the absence of coordinated national responses, institutional approaches to the treatment of international students have differed from one university to another. Such differences can be linked to the differentiated nature of the South African higher education sector, where the capacity of institutions to deal with Covid-19 related challenges and to respond comprehensively to the needs of different groups of international students varies in accordance with the availability of relevant structures, systems, digital platforms and other resources.

As a reflective practitioner account, the article draws on the experience of the authors in higher education internationalisation as well as on the collective experience of a community of practice of the International Education Association of South Africa, which represents the majority of public universities in the country.

\section{Keywords}

Covid-19; higher education; inclusion; internationalisation practice; international students;

South Africa

i Dr Samia Chasi is the Strategic Advisor for the International Education Association of South Africa (IEASA) and a Research Fellow at the University of the Free State, South Africa. ORCid: 0000-0003-1896-0248. Email: samiachasi@yahoo.com

ii Ms Orla Quinlan has been IEASA President 2019-2020 and is Director: International Office, Rhodes University, South Africa. ORCid: 0000-0001-7464-4026. Email: o.quinlan@ru.ac.za 


\section{Introduction}

The Covid-19 pandemic has impacted higher education (HE) around the world in unprecedented ways, causing major disruptions to the teaching, learning and research functions of universities. Internationalisation activities, generally aimed at improving the quality of education and research, have also been adversely affected, most notably regarding restrictions on the international mobility of students and staff for study and research purposes as well as participation in meetings and conferences.

This article is a reflection on how Covid-19 has impacted HE internationalisation in South Africa. In particular, it focuses on how international students at the country's public universities have been affected by national and institutional responses to the pandemic. Written at a time where Covid-19 related restrictions are ongoing and the full impact of the pandemic cannot yet be foreseen, this article aims to create a public record of the impact of the global pandemic on international students in South Africa over a nine-month period, from March to December 2020.

By addressing the specific challenges and constraints international students have faced and highlighting that some of them are at risk of being left behind in terms of the successful completion of the 2020 academic programme, this article critically discusses the question of inclusion in current Covid-19 related government policy and institutional practices. The authors present a reflective practitioners' account, in which they draw on their extensive experience in HE internationalisation, most notably their current roles in the International Education Association of South Africa (IEASA). ${ }^{1}$

Based on their access to and involvement in the Directors Forum (DF), the authors share their personal reflections on the interactions of the members of this forum, who are an important community of practice for IEASA's institutional members, thus drawing on a collective voice of South African higher education institutions (HEIs). This article is informed by engagements of DF members, who are the directors of international offices of IEASA's member institutions. Through this platform, IEASA has established a community of practice, which has played a key role at this time of crisis by fostering learning and exchange to address common challenges and find practical solutions. Through formal meetings and communication via informal channels such as a WhatsApp group, the DF members engage regularly to keep each other abreast of the latest developments, identify common challenges, share examples of institutional responses to such challenges and learn from each other's good practices. As Chasi (2020, para. 10) notes, this engagement has "created a deep sense of community, as directors realised that the challenges they face are not unique to individual institutions, although their extent and severity can vary from one university to another". In the case of the Covid-19 pandemic, such a community of practice has been particularly important because institutional approaches to the implementation of

1 IEASA is a registered, non-profit organisation (NPO) dedicated to advancing the internationalisation of South African HE. It currently comprises 23 out of the 26 universities that make up the South African public HE sector. The following three institutions are currently not members of IEASA: Mangosuthu University of Technology, Sol Plaatje University and University of Mpumalanga. 
Covid-19 related government policy and its impact on internationalisation have not been coordinated and aligned at the national level.

\section{HE Internationalisation in South Africa}

\section{General internationalisation trends}

Internationalisation has been a concern of increasing importance for South African universities since the end of apartheid and its resultant international sanctions and academic boycott. After 1994, the country saw a considerable influx of international students. Reflecting on IEASA's history, Jooste (2007) notes that South African HEIs were initially under-prepared for the handling of international students coming to the country in increasing numbers. The first consultative meetings of the HE sector dealt mainly with issues arising from the presence of international students on South African campuses, including the potential for income generation, matters pertaining to immigration, language of instruction, the evaluation of non-South African qualifications as well as the provision of services to international students (Jooste, 2007). To help address these issues at a national level, it was recommended that a voluntary association be established, and IEASA was launched in January 1997 (Swemmer, 2018), resulting from the sector's need to respond to the influx of international students.

Internationalisation in the South African HE sector is no longer considered simply a matter of dealing with the presence of international students on university campuses across the country (Chasi, 2019). Internationalisation efforts of South African universities included, especially in the early years, setting up international offices and developing institutional internationalisation policies as well as activities regarding the recruitment of international students and staff, the mobilisation of local students and staff and the integration of an international dimension into programmes and curricula (Kishun, 2006). Over the past few years, there has been a focus on strengthening internationalisation of the curriculum (IoC) and internationalisation at home ( $\mathrm{IaH}$ ) dimensions as part of increased efforts to advance HE internationalisation in South Africa more equitably and inclusively. Most recently, the use of virtual exchanges and Collaborative Online International Learning (COIL) to internationalise the curriculum and to foster intercultural competence and multicultural learning has been gaining momentum, accelerated by Covid-19 related changes to the way we study, do research and work.

\section{Policy uncertainty}

In November 2020, it was formally announced that South Africa's first national policy framework for $\mathrm{HE}$ internationalisation has been ratified. However, leading up to that point, South African universities dealt with internationalisation mostly in their individual capacities for more than 20 years, with IEASA playing a facilitating and supporting role. As highlighted by Jooste and Hagenmeier (2018), IEASA identified the need for a national internationalisation policy as early as 2003 and was a major driving factor in its 
development until the Department of Higher Education and Training (DHET) published its Draft Policy Framework for the Internationalisation of Higher Education in South Africa for public comment in 2017.

In May 2020, IEASA called on the South African government to reaffirm its commitment to HE internationalisation by adopting the policy and supporting its implementation across the sector (IEASA, 2020). The need for policy clarity on internationalisation was also highlighted in a recent report on the country's HE system in the period 2005-2017, which notes that policy uncertainty brings about challenges, particularly in light of calls by some parliamentarians to introduce quotas for the recruitment of international students and academic staff, which creates political pressures on universities and funding bodies (Essop, 2020).

\section{Inequality and underfunding}

Apart from a long period of policy uncertainty, HE internationalisation in South Africa happens in a challenging HE environment characterised by inequality and underfunding. In its policy framework for HE internationalisation in South Africa, the DHET (2019) includes as rationales the positioning of the country's HE sector to be competitive in a globalised world, the advancing of HE quality as well as the benefiting of society at large and enhancing opportunities for HE to contribute to the public good. However, HE internationalisation has not been advanced evenly across the country's universities. More than 20 years after the end of apartheid, the internationalisation policy recognises that historically disadvantaged institutions (HDIs) "still have very low levels of international relations and are not yet, therefore, benefiting from internationalisation to the degree that they could" (DHET, 2019, p. 21).

In a university sector that is generally underfunded, ${ }^{2}$ when compared internationally, HE internationalisation competes for limited resources with other institutional priorities and is often put on the back burner of institutional initiatives. IEASA recognises that there is no 'one size fits all' approach to HE internationalisation in South Africa. The diversity of its member institutions manifests itself in different historical, geographical and operational contexts as well as in different institutional priorities and different levels of financial and human resource capacity allocated to internationalisation. In this context, it is imperative that internationalisation endeavours of universities are increasingly relevant and aligned to other institutional and national goals, contributing to transformation, nation-building and the public good.

2 While the level of HE spending has increased over the years, government subsidies for South Africa's 26 public universities have been declining in real terms, and one of the recommendations made by the Commission of Enquiry into Higher Education and Training (2017) was that government should work towards funding the university sector with one per cent of GDP. 


\section{Internationalisation policy focus}

As highlighted in the internationalisation policy framework, South African HEIs must design their internationalisation activities in such a way that priority is, first and foremost, given to South Africa's interests. Thereafter:

... where possible and relevant, the following order of priority focus should be observed in terms of interests: the SADC [Southern African Development Community] states; the rest of the African continent; BRICS [Brazil, Russia, India, China, South Africa]; the global South and emerging economies; and the world beyond.

(DHET, 2019, p. 22)

When it comes to student enrolments, this priority focus is already manifest in so far as the majority of international students in South Africa are African and mostly from SADC countries. The SADC focus is in line with the SADC Protocol on Education and Training Development (SADC, 1997), which recommends that member states reserve at least five per cent of their university admissions for students from other SADC nations.

\section{International students in South Africa}

\section{International student trends}

Since the end of apartheid, South Africa has been a popular destination for international students, particularly from the continent. Factors contributing to its attractiveness include the presence of several South African HEIs in major international university rankings, a well-established HE sector offering internationally recognised qualifications, the use of English as the main medium of instruction and relatively low costs of living.

International students are generally distinguished into two main categories: degreeseeking students and short-term students, of which the former are the majority of international students in South Africa. A total of 68036 international degree-seeking students were registered at South African universities in 2017, accounting for approximately 6.5 per cent of the total student population of 1036984 (CHE, 2019). ${ }^{3}$

Between 2005 and 2017, international student numbers grew by 32.5 per cent (Essop, 2020). Almost half of this growth is accounted for by an increase in postgraduate enrolments, particularly from the rest of Africa (ibid.). Between 2005 and 2017, international postgraduate enrolments increased by 106.4 per cent, and at the doctoral level, international students as a proportion of total doctoral enrolments increased from 23.1 per cent to 39.6 per cent (ibid.). This means that international students make a significant contribution towards national development, specifically the goal of having 5000 doctoral graduates annually by 2030 (NPC, 2012).

3 It is worth noting in this regard that if the total numbers are disaggregated further, it becomes apparent that 26740 international students, which equals almost 40 per cent of all international students, are not pursuing their studies in South Africa but are registered for distance education programmes, offered mostly through the University of South Africa (Unisa), the country's dedicated distance education institution (IEASA, 2019). 
The vast majority of international degree-seeking students registered at South African universities are African. In 2017, a total of 60334 students were from other countries on the continent, making up 88.7 per cent of all international students. What is more, 48641 students came from the SADC region, accounting for 71.5 per cent of international student enrolments (CHE, 2019). Many of these students come to South Africa for a variety of reasons including political instability, economic hardship and negative impacts of climate change in neighbouring countries.

Apart from degree-seeking students, South African HEIs also host international students for short-term periods and study abroad semesters. The vast majority of these students come from North America and Europe on a fee-paying basis or on the basis of fee-waiver agreements as part of institutional exchange agreements. However, national data from South African sources is not widely and easily available for this category, as it has not been gathered systematically and consistently across the sector and over time. However, Open Doors states, for example, that 341751 students from the Unites States (US) studied abroad for academic credit for periods in-between eight weeks or less to one academic year in 2017/2018. Of these students, 6001 chose South Africa as their study destination, making it the 11th most popular destination for US students in that year (Open Doors, 2019).

Notwithstanding differences in types of students and numbers, international students are present on the vast majority of university campuses across South Africa. All of IEASA's member institutions have established international offices to serve as first point of contact for international students and to provide them with general guidance and advice on matters related to their studies in South Africa.

\section{University services for international students}

Student services for international students are organised very differently across the range of South African HEIs, indicating varying degrees of importance assigned to internationalisation as an institutional priority. In some universities, internationalisation is a key part of the institution's overall forward-looking strategy, driven by the Vice-Chancellor. In others, internationalisation competes for attention with more pressing local issues such as the impact of water shortages or failing municipality services.

While international offices have been established, their positioning within each institution, function, size, capacity, role and funding model vary greatly. Most importantly, the extent of the services available to international students in any particular institution is influenced by their funding model. While some international offices are allocated a modest university budget, others generate funding through their activities in order to pay for their costs, including substantial income through bespoke short courses and study abroad programmes. In some international offices, a mixed model is adopted combining core university funding and income generated from office activities. Some universities charge international student levies and others do not. The levies themselves are also allocated differently in each institution to either the central university budget or the relevant faculty and other units including the international office, or a combination of both. 
Well-resourced offices tend to deal with internationalisation more broadly and comprehensively, including international visitors and events as well as the entire cycle of an international student's experience from initial marketing and recruiting to graduation. The services provided for international students include orientation, registration and a range of specific international student services pertaining to immigration and medical aid, as a core visa requirement. In contrast, smaller offices may deal with only some aspects of these student services, with others being provided by general student service units usually housed within the Registrar's and student affairs divisions.

As alluded to earlier, there is an unevenness about the prevalence of internationalisation and service provision for international students on South African campuses. Against this backdrop, Covid-19 has affected universities and international students in South Africa differently.

\section{Covid-19 Impact on HE Internationalisation: The Case of International Students in South Africa}

The impact of Covid-19 related restrictions on international student mobility has affected South African HEIs to varying degrees. On the one end of the spectrum, universities focused their responses to the pandemic mainly on the presence of a small number of international students. At the other end, a whole variety of international activities were at risk. For institutions that relied on income generated through international activities such as study abroad programmes and winter/summer schools, financial losses suffered due to Covid-19 potentially threatened the sustainability of the very same initiatives and programmes and, in some instances, the sustainability of the funding model of the international office.

\section{The impact of Covid-19 on international students in South Africa}

In response to Covid-19, the South African government implemented measures following a risk-adjusted approach, taking into account several factors including but not limited to the level of infections, the rate of transmissions, the capacity of health facilities as well as the economic and social impact of implemented restrictions. This approach included a fivelevel alert system, which determines the level of restrictions to be applied during different phases of the national state of disaster. The system ranges from lockdown level 5, with a high spread and a low health system readiness, to lockdown level 1, with a low spread and a high health system readiness. ${ }^{4}$

All students have been affected by measures implemented in response to Covid-19 such as travel bans, campus closures and the move to online teaching and learning. However, aspects of these measures have created specific challenges for international students that are experienced differently by local students or not shared by them at all. In addition, as the

4 More detailed information about the alert levels is published by the South African government and available at https://www.gov.za/covid-19/about/about-alert-system 
various levels of lockdown were adjusted, there was an increasing differentiation between the impact on students located inside South Africa, both local and international, and those outside the country.

\section{Travelling home before lockdown}

When universities closed for early recess from 18 March 2020, students were asked to vacate university premises and return home. As IEASA (2020) highlights, such requests created challenges for local and international students alike, particularly when travelling home was linked to fears of health risks as well as logistical and financial difficulties. International students faced some additional challenges in that regard. For example, in contrast to their local counterparts, international students often stay in residences even during recess periods and return home only at the end of their academic programme or academic year or upon completion of their studies. In this instance, however, they were expected to make international travel plans at short notice and at a cost not budgeted for. Students from countries identified as high-risk were particularly concerned about leaving South Africa and their prospects of being able to return once campuses reopened. Further challenges arose due to flight cancellations and border closures in the wake of international travel bans and, in some instances, international students were unable to travel due to pending visa extensions.

In effect, many full-time international students from beyond the SADC region could not leave the country. Study abroad students generally repatriated and resumed courses in their home institutions. With only a few days between the national lockdown being announced and it taking effect on 26 March 2020, some students had to leave the country in such a hurry that they left behind personal belongings and learning materials. Jooste and Hagenmeier (2020) point out that it was generally expected at the time that they would be able to return to their universities soon.

\section{Contact and communication}

International students are generally requested to update their contact details on an annual basis. However, after campus closures, some students could no longer be reached via the contact details provided, especially if they had crossed the border and were no longer accessing South African mobile networks. Similarly, receiving electronic communication from their institutions was a challenge for students who had left campus and no longer had access to computers, data, networks and electricity. Under such conditions, institutions experienced considerable difficulties in establishing the whereabouts of their international students. Some discovered that students they thought had left the country actually stayed within the borders of South Africa.

\section{Accommodation}

In cases where international students were, for a variety of reasons, unable to travel home or find alternative accommodation, universities had to make arrangements for continued care and support, including accommodation. Some international students were therefore 
allowed to stay in university residences on campus, with strict regulations to meet the necessary requirements regarding health standards and social distancing. Others were moved to alternative accommodation off campus. Even in cases where students stayed on campus, the provision of services for them was severely disrupted due to the closure of campus facilities as well as the shift to staff working from home, with personnel available on site reduced to a bare minimum.

Students who moved in with relatives or friends also faced specific challenges pertaining to accommodation, as they no longer had their own dedicated space. In one instance, a group of Zimbabwean scholarship students used their travel allowance to club together and rent a place, anticipating that it would be easier to continue with their studies in South Africa, in spite of inadequate financing. They feared returning home to places where there might be very little connectivity and thought they would access most of the same adaptive measures as South African students if they remained. As the lockdown continued for much longer than initially expected, they eventually ran into financial difficulty and required assistance from their host university to survive.

\section{Immigration matters}

In January 2020, the Department of Home Affairs (DHA) provided visa exemptions until the end of March, which allowed universities to register international students who had applied for extensions of their study visas inside the country on the basis of Visa Facilitation Services (VFS) receipts, as proof that their applications had been submitted. However, when campuses were closed in line with Covid-19 related restrictions, these same students were initially informed that they could not leave South Africa without the risk of being declared undesirable and unable to return. Some students crossed the border regardless, and the consequences of this decision remained to be seen until international students were finally permitted to return and re-enter the country to resume their studies.

On 26 March 2020, the Minister of Home Affairs issued a range of concessions for foreigners inside South Africa, including international students, and extended their visas until 31 July 2020 (DHA, 2020a), which permitted students to retain the same legal status as they held prior to lockdown. Subsequently, the concessions were further extended to 31 October 2020 (DHA, 2020b). While these concessions assisted students whose visas expired during lockdown in terms of their legal status in the country, there were other material hardships for students due to the closure of VFS offices and the unavailability of services. To mention some examples, there was no facility to change the conditions of visas, which affected students who wanted to change universities and could not register at their new institution. Students who had completed their $\mathrm{PhD}$ studies and were due to commence postdoctoral research could not apply for the correct visa and missed funded research opportunities. Pharmacy students, who were to complete their final year and take up internships, were delayed, which will impact on their career opportunities for 2021.

The DHET announced on 26 August 2020 that the target for completion of the 2020 academic year will be the end of February 2021 (DHET, 2020c). This means that some international students will need to extend their study visas beyond December 2020. 
Even if an extension is granted automatically by the DHA, students will incur additional, previously not anticipated expenses, such as for maintaining their medical aid cover, which is a core study visa requirement.

As the examples relating to travel, communication, accommodation and immigration show, the specific circumstances of international students are generally complex and varied. This means that universities have to accommodate international students often on a caseby-case basis, requiring ad-hoc and tailor-made solutions. In the context of Covid-19, the need for differentiated services was exacerbated even further, as students found themselves in different scenarios, depending on how measures implemented to prevent the spread of the pandemic affected them. Whatever services they provided, universities had to be mindful of the different situations international students found themselves in - on campus; off campus but in a host institution location; elsewhere in the country or at home outside South Africa.

\section{Inclusion in Times of Covid-19}

The question of inclusion arises particularly in the context of national and institutional plans to assist students in successfully completing the 2020 academic year despite severe disruptions. The Minister of Higher Education, Science and Innovation proclaimed that no student is to be left behind in that regard (SA News, 2020). However, it appears that several groups of students are at a high risk of being left behind, most notably students "living in conditions that are not conducive to online learning, without access to computers and laptops, affordable data, reliable internet connectivity, electricity or a dedicated physical space in which to study" (IEASA, 2020, p. 2). Another group of students at risk are international students, especially those who were, in adherence of lockdown regulations, outside the borders of South Africa until they were eventually able to return under lockdown level 1, which took effect on 21 September 2020.

In early June 2020, the DHET observed that the numbers of international students in university residences on and off campus were small (DHET, 2020b). Taking into account reports from universities that considerable numbers of their international students remained elsewhere in the country, the question still arose of how the DHET and other government departments accommodated the needs and interests of international students outside South Africa. These students were not at the forefront of considerations and plans for the successful completion of the 2020 academic year, as such plans, at both national and institutional levels, targeted mainly local students and international students who remained in South Africa.

\section{Return to campus}

Returning to campus was particularly important for students who were living and studying in challenging circumstances. However, in planning the phased reopening of campuses and resumption of face-to face teaching, the DHET confirmed that only under lockdown level 1, "International students who were residing outside of the country during the 
lockdown period may return (provided that international travel is permitted)" at that time (DHET, 2020b, p. 9). These students were thus essentially excluded from opportunities to return to campus in a staggered approach, in the same way as local students. This affected the students' ability to access study and research facilities on campus, which was, in turn, likely to negatively impact their academic performance and progress.

To further illustrate the complexities, on 30 April 2020 the DHET (2020a) announced that the only exception to campus closures under lockdown level 4 would be the controlled return of clinical training students in their final year to assist with ongoing health management efforts of the Department of Health (DoH). However, this directive did not make any explicit provision for the return of international students studying in their final year towards qualifications in the relevant disciplines. It was reported in the news that some final-year students returned to South Africa from Namibia at the end of May (Kandovazu, 2020). As Jooste and Hagenmeier (2020) note:

There was no clarity about whether this would include international students; the wording was at least wide enough to allow for this. Stakeholders interpreted the regulations in different ways, but at least a limited number of international final-year medical students returned from Lesotho.

(para. 8-9)

The Department of Co-Operative Governance and Traditional Affairs (COGTA, 2020) issued regulations for lockdown level 3 indicating that "daily commuters from neighbouring countries who attend school in the Republic" (p. 13) may be allowed entry. However, no similar provision was explicitly made for international students from such countries, revealing inconsistencies in the treatment of international school learners and international students.

On 26 August 2020, the DHET stated that in case international travel be permitted under lockdown level 2, "Priority may have to be given to Registrars and senior Medical Students" (DHET, 2020c, p. 11). Again, no further details regarding the implementation of such provision were provided.

\section{Remote learning}

When the DHET announced that international students would be allowed to return to campuses only under lockdown level 1, it also stated that "These international students will be supported through remote learning support until they return" (DHET, 2020b, p. 8). In practice, the capacity of universities to provide remote learning and support differed significantly. While some institutions, most notably research-intensive universities, were able to implement remote teaching and learning as an emergency measure from as early as the second term starting in April 2020, others, especially HDIs, were still struggling to adequately provide teaching and learning services online when the phased re-opening of campuses started in June 2020.

Furthermore, institutional efforts to support students by providing learning devices and data were, for the most part, limited to local and international students in South Africa for 
logistical and financial reasons. For example, laptops were more laborious and expensive to transport across borders, and data deals were more difficult to negotiate with companies outside South Africa's borders. At the same time, challenges with internet connectivity and bandwidth are often even more pronounced in students' home countries on the continent. Universities made attempts to support students by negotiating with mobile communications companies in neighbouring countries and also approached alumni networks for assistance. In some instances, students in Lesotho, Namibia and Botswana received laptops. There are also cases where universities were able to support students with free data or rebates or data allowances. Data was made available to some students in neighbouring countries, especially in Lesotho and eSwatini.

Despite these efforts, universities did not generally have the requisite contacts, mechanisms and budgets in place to support students who were outside of the country, particularly in the initial phase of adapting to the 'new normal'. There was a distinct time lag in finding ways to assist international students, which is a continuing challenge. For example, the University of the Witwatersrand, Johannesburg (Wits, 2020a) announced on 14 April 2020 that it would re-open on 20 April and institute an emergency remote teaching and learning programme to help minimise the time lost in the academic project. A few days later, Wits (2020b) confirmed that students registered on one of the four major mobile networks operating in South Africa would receive $30 \mathrm{~GB}$ of data at no cost for one month. However, it took four months until the University announced that international students based in Lesotho, eSwatini and Zimbabwe would also receive data from Wits (Belle, 2020). As this example shows, the support for international students was, even where available, delayed and neither uniform nor comprehensive across the board.

\section{Reasons for lack of inclusive approaches}

To a large extent, the lack of adequate consideration for international students can be ascribed to the unprecedented nature of the Covid-19 pandemic and the lack of relevant national and institutional resources, structures, systems, digital platforms and experiences in dealing with such a crisis. It quite literally caught everyone by surprise. Of greater concern is the lack of clarity and detail in government directives, which, in the absence of coordinated, sector-wide approaches, left each university to interpret them differently, as in the case of the return of final year medical students.

Various concerns arose regarding the return of international students from outside South Africa, as their reintegration into classes and campus life was expected to involve additional time and resources, particularly regarding requirements for quarantine and self-isolation. Furthermore, it was anticipated that international students who had left the country without awaiting the outcome of their ongoing visa extension applications might experience challenges with their visas upon re-entry. In effect, students from the SADC region returned to South Africa on visitors' visas, acquired at the border and, with DHA concessions, collected their study visa application outcomes inside South Africa. A proportion of students decided not to return to South Africa in 2020 and continued to 
learn online. Their visa outcomes await collection at VFS offices, where they will be kept for a few months before being returned to the DHA. Some students may be anticipating collecting visa outcomes early in 2021, as they come to register for the new academic year.

A possible reason why considerations and plans did not specifically cater for international students is the lack of well-informed representation at the national level. For example, when the Department of Higher Education, Science and Innovation (DHESI) established a dedicated Covid-19 Team in mid-March 2020, this did not include representation of bodies that can specifically speak for international students. This might have been an oversight giving expression to the lack of prioritisation of HE internationalisation and existing policy uncertainty at the time, as indicated earlier.

The lack of adequate and consistent concern for the needs of international students can negatively affect their individual study experiences. The psychological impact of being asked to leave and the delays in being accommodated to participate in online teaching and learning and in being allowed back onto campus may affect international students' confidence in their home institutions' ability to treat them equally and equitably in comparison to local students. In the long-term, this carries the risk of more far-reaching reputational damage to the entire sector. In that regard, Jooste and Hagenmeier (2020) point out that the way international students were being treated during the ongoing Covid-19 crisis may determine South Africa's ability "to retain its position as a regional higher education hub and whether it will be able to be a driver for $\mathrm{PhD}$ capacity development in the SADC region and Africa following the pandemic" (para. 2). They note further that any unjustified discrimination of international students "may infringe the country's internationally celebrated Constitution, taint South Africa's standing as a higher education hub and jeopardise its existing reputation as a preferred destination for international students" (para. 23). This is especially true if students are unable to successfully complete their academic programme.

\section{Way forward}

For the reasons mentioned above, it is imperative that the government's aim to not leave any student behind is achieved. In a position paper published in May 2020, IEASA (2020) appealed to universities and other HE stakeholders to ensure that international students are not left out of considerations for the successful completion of the 2020 academic programme. Learning from experiences so far, this means that internationalisation considerations need to be given more prominence in ongoing and future responses to Covid-19. It also requires a more deliberate engagement with the needs and interests of international students, which must be taken into account when designing initiatives and programmes at both national and institutional levels. Such initiatives and programmes should be equitable and afford international students the same opportunities as local students. Plans to facilitate the continuity of academic and support services need to cater for international students who are inside the country as well as those who are outside the border of South Africa. 
Based on the collective experience of IEASA's members (IEASA, 2020), institutions would benefit from greater alignment and coordination of efforts to combat Covid-19 at national level, including the collaboration of different government departments impacting on international student issues, most notably the DHESI, the DHA and the Department of International Relations and Cooperation (DIRCO). Institutions, especially those that are underprivileged and under-resourced, also stand to gain from more inclusive, sector-wide approaches, for example, regarding the pooling of institutional resources to create regional or national platforms for online teaching as well as the negotiation of internet and datarelated deals with mobile communications companies (ibid.).

\section{Concluding Remarks}

At the global level, the full impact of the Covid-19 pandemic on the future of HE internationalisation is as yet unclear. As a member of the Network of International Education Associations (NIEA), IEASA supports a recently published statement reaffirming the value and importance of international education and research, highlighting that measures implemented to limit international HE should be time-bound (NIEA, 2020). This includes any restrictions on international students.

In South Africa, the full impact of restrictions implemented in response to Covid-19 is difficult to predict at a time when it is not yet clear how successfully the 2020 academic year will be completed. Similarly, it has not yet been established how many international students were able to make use of online teaching and learning, where offered, and how this has impacted on their academic performance.

There is some indication that the 'new normal' of teaching and learning will include blended approaches. Similarly, it can be expected that some of the new ways of working remotely will find their way into service provision for international students. At the same time, international students are likely to want and need a physical campus experience to enhance their immersion and integration by ensuring conducive study conditions and human interactions.

Covid-19 has undoubtedly caused a disruptive shock to the core functions of universities. However, it also provides HEIs with an opportunity to adapt positively to an ever-changing internationalisation environment and emerge as institutions that are smarter, more inclusive and more responsive. This includes adopting creative and innovative approaches to the way in which they service and support different categories of students, including international students, who make a very valuable contribution to the intellectual and cultural diversity of South African universities and the development of the South African HE sector.

\section{Research Ethics}

Work on this article did not involve any research participants and therefore did not require ethical clearance. 


\section{Conflict of Interest}

The authors declare that they do not have financial or personal relationships that may have inappropriately influenced them in writing this article.

\section{Funding}

This work has not received any financial support.

\section{References}

Belle, Z. (2020, August 18). Wits international students to receive data. Wits Vuvuzela. http://witsvuvuzela. com/2020/08/18/wits-international-students-to-receive-data/

Chasi, S. (2019). North-South partnerships in public higher education: A selected South African case study. [Doctoral dissertation], University of the Witwatersrand, Johannesburg, South Africa. http://wiredspace.wits. ac.za/handle/10539/28064

Chasi, S. (2020, April 9). COVID-19 has put HE internationalisation under review. University World News. https://www.universityworldnews.com/post.php?story $=20200408093750683$

CHE (Council on Higher Education) (2019). VitalStats - Public Higher Education 2017. https://firebasestorage.googleapis.com/v0/b/che2020-c5efd.appspot.com/o/website\%2F1svgvakokgb1?alt=media \&token $=\mathrm{d} 76 \mathrm{cb} 24 \mathrm{a}-5931-4 \mathrm{c} 45-\mathrm{b} 652-590563314 \mathrm{c} 92$

COGTA (Department of Co-Operative Governance and Traditional Affairs) (2020, May 28). Disaster Management Act, 2002 (Act No. 57 of 2002): Determination of Alert Levels and Hotspots. Government Gazette, 659(43364). Republic of South Africa.

Commission of Enquiry into Higher Education and Training (2017). Report of the Commission of Enquiry into Higher Education and Training to the President of the Republic of South Africa. http://www. thepresidency.gov.za/sites/default/files/Commission\%20of\%20Inquiry\%20into\%20Higher\%20 Education\%20Report.pdf

DHA (Department of Home Affairs) (2020a, March 26). Directions issued in terms of regulation 10(8) of the regulations made under section 27(2) of the Disaster Management Act, 2002 (Act No. 57 of 2002): Measures to prevent and combat the spread of COVID-19. Government Gazette, 657(43162). Republic of South Africa.

DHA (2020b, July 31). Amendment of directions issued in terms of regulation 10(8) of the regulations made under section 27(2) of the Disaster Management Act, 2002 (Act No. 57 of 2002): Measures to prevent and combat the spread of COVID-19. Government Gazette, 661(43572). Republic of South Africa.

DHA (2020c, August 25). Amendment of directions issued in terms of regulation 4(8) of the regulations made under section 27(2) of the Disaster Management Act, 2002 (Act No. 57 of 2002): Measures to prevent and combat the spread of COVID-19. Government Gazette, 662(43650). Republic of South Africa.

DHET (Department of Higher Education and Training) (2019). Policy framework for internationalisation of higher education in South Africa. https://www.dhet.gov.za/Policy\%20and\%20Development\%20 Support/Policy\%20Framework\%20for\%20Internationalisation\%20of\%20Higher\%20Education $\% 20$ in $\% 20$ South\%20Africa.pdf

DHET (2020a, April 30). Minister of Higher Education, Science and Innovation statement on the measures to phase-out the lockdown and phasing in of PSET strategic functions. https://www.dhet.gov.za/ SiteAssets/Media\%20Statement\%202020/PHASING\%20OUT\%20THE\%20LOCKDOWN\%20 MEASURES\%20final.pdf 
DHET (2020b, June 8). Directions for criteria to return to public university and private higher education institution campuses as part of a risk-adjusted strategy for a phased-in return from level 3: Issued in terms of the Disaster Management Act, 2002 (Act No. 57 of 2002). Government Gazette, 660(43414). Republic of South Africa.

DHET (2020c, August 26). The Minister of Higher Education, Science and Innovation, Dr Blade Nzimande's statement on Covid-19 alert level 2 measures in the post school education and training sector. https://www.dhet. gov.za/SiteAssets/Media\%20Statement\%202020/Minister\%20Nzimande $\% 27 \mathrm{~s} \% 20$ Statement $\% 20$ on\%20Level\%202.pdf

Essop, A. (2020). The Changing Size and Shape of the Higher Education System in South Africa, 2005-2017. Ali Mazrui Centre for Higher Education Studies, University of Johannesburg. https://www.uj.ac.za/ faculties/facultyofeducation/ali-mazrui-centre

IEASA (International Education Association of South Africa) (2019). Study South Africa - The guide to South African higher education. Engaged universities: Comprehensive internationalisation - a dialogue between local and global realities (18th ed.). IEASA. https://studysa.africa/

IEASA (2020, May 29). Position paper - higher education internationalisation in South Africa in the context of the Covid-19 pandemic: Impact on international students. IEASA. http://ieasa.studysa.org/wp-content/ uploads/2020/05/IEASA-position-paper_COVID-19_May2020_Final.pdf

Jooste, N. (2007). 10 Years of IEASA history. IEASA. http://studysa.org/wp-content/uploads/2019/03/ 10-years-of-IEASA-history.pdf

Jooste, N. \& Hagenmeier, C. (2018). Draft policy framework for the internationalisation of higher education in South Africa: An IEASA perspective. In Study South Africa - The guide to South African higher education (17th ed., pp. 5-6). IEASA.

Jooste, N. \& Hagenmeier, C. (2020, July 9). South Africa's destination reputation is on the line. University World News. https://www.universityworldnews.com/post.php?story $=20200707102247518$

Kandovazu, E. (2020, June 3). Namibian students return to SA. Informanté. https://informante.web.na/ namibian-students-return-to-sa/

Kishun, R. (2006). Introduction: The internationalisation of higher education in South Africa - Progress and challenges. In R. Kishun (Ed.), The internationalisation of higher education in South Africa (pp.1-12). IEASA.

NIEA (Network of International Education Associations) (2020, July 24). Statement on the importance of international higher education and research. IEASA. http://ieasa.studysa.org/wp-content/uploads/2020/ 07/NIEA-Statement-on-the-importance-of-international-higher-education-and-research.24-July2020.pdf

NPC (National Planning Commission) (2012). National Development Plan 2030: Our future - make it work. The Presidency. https://www.gov.za/sites/default/files/gcis_document/201409/ndp-2030-ourfuture-make-it-workr.pdf

Open Doors (2019). 2019 Fast facts. https://opendoorsdata.org/fast_facts/fast-facts-2019/

SADC (Southern African Development Community) (1997). Protocol on education and training development in the Southern African Development Community. https://www.sadc.int/files/3813/ 5292/8362/Protocol_on_Education_Training1997.pdf

SA News (2020, May 1). Government vows to leave no student behind. 'The Skills Portal'. https://www. skillsportal.co.za/content/government-vows-leave-no-student-behind

Swemmer, D. (2018). Walk together and look back to move forward! In IEASA, Study South Africa - The guide to South African higher education (17th ed., pp. 50-52). IEASA. 
Wits (University of the Witwatersrand) (2020a, April 14). Wits switches to remote online teaching and learning from 20 April 2020. https://www.wits.ac.za/covid19/covid19-news/latest/wits-switches-to-remoteonline-teaching-and-learning-from-20-april-2020.html

Wits (2020b, April 19). COVID-19 Update 24: Data access: All four major mobile service providers on board. https://www.wits.ac.za/covid19/covid19-news/latest/covid-19-update-24-data-access-all-fourmajor-mobile-service-providers-on-board.html

\section{How to cite:}

Chasi, S. \& Quinlan, O. (2021). Inclusion in Times of Covid-19: The Case of International Students in South Africa. Journal of Student Affairs in Africa, 9(1), 205-221. DOI: 10.24085/jsaa.v9i1.1439 